\title{
Spine Cancer pT1 TNM Finding v8
}

National Cancer Institute

\section{Source}

National Cancer Institute. Spine Cancer pT1 TNM Finding v8. NCI Thesaurus. Code C136585.

Spine cancer with tumor confined to one vertebral segment or two adjacent vertebral segments. (from AJCC 8th Ed.) 